\title{
PENGARUH KONFLIK KEAGENAN \\ TERHADAP CORPORATE GOVERNANCE \\ DAN KINERJA PERUSAHAAN
}

Oleh : Wahyu Manuhara Putra; SE, MSi, Ak.

Fakultas Ekonomi

Universitas Muhammadiyah Yogyakarta

JI Ringroad Barat, Kasihan, Bantul, Y'ugyakarta

\begin{abstract}
This study aimed to test whether the Corporate Governance associated the Agency Conflicts. This research used exploratory principal components analysis and kanonikal analysis on 6 individual governance variables to get the 5 factors representing different dimensions of corporate governance and measures the agency conflict firms based on 7 agency conflict proxies used in the literature. Results of analysis found that companies with greater agency conflict has a mechanism for better corporate governance, in particular thiat the low ownership structure has a high impact on institutional ownership. Overall, the results support the theory that the existence and role of corporate governance mechanisms on firm is a function of agency conflict in the company.
\end{abstract}

Key word: Agency Conflicts, Corporate Governance, exploratory principal components analysis, kanonikal analysis. 


\section{PENDAHULUAN}

Kajian mengenai corporate governance meningkat pesat seiring dengan terbukanya berbagai skandal keuangan baik yang ada di luar negeri maupun yang terjadi di Indonesia. Corporate Governance membantu terciptanya hubungan kondusif dan bertanggungjawab diantara elemen perusahaan (dewan komisaris, dewan direksi, dan para pemegang saham) dalam rangka meningkatkan kinerja perusahaan. Pada hubungan tersebut, dewan komisaris memastikan bahwa manajemen bekerja demi kepentingan perusahaan dan pemegang saham. Corporate governance dapat dikembangkan dari igency theory yang menjelaskan bahwa hubungan - agensi muncul ketika principal mempekerjakan agent dan mendelegasikan wewenang pengambilan keputusan kepada agent tersebut (Jensen dan Meckling, 1976). Sebagai pengelola perusahaan, manajer akan lebih banyak mengetahui informasi internal dan prospek perusahaan dibandingkan pemegang saham. Adanya information asymmetric antara manajer dan pemegang saham menimbulkan konflik kepentingan (agency conflicts). Konflik kepentingan tersebut mendorong manajer untuk memaksimalkan utilitasnya dengan mengorbankan pemegang saham. Akibatnya, pemilik perusahaan membuat mekanisme dalam memantau aktivitas manajerial dan membatasi perilaku manajerial yang tidak diinginkan (Jensen dan Meckling, 1976). Sebagai hasilnya, struktur corporate governance terkait dalam membantu mengurangi konflik keagenan.

Besarnya agency conflicts bervariasi antar perusahaan tergantung pada kemauan manajer melaksanakan preferensi mereka yang bertentangan dengan maksimalisasi nilai, kompleksitas lingkungan operasi perusahaan, daya tarik perquisites, dll (Jensen dan Meckling, 1976). Karena agency problems bervariasi antar perusahaan, struktur governance yang dibutuhkan untuk mengatasi masalah tersebut juga cenderung Lervariasi. Dampaknya, setiap hubungan antara berbagai mekanisme governace dan berbagai aspek kinerja organisasi tidak mungkin seragam pada semua perusahaan. Akibatnya, supaya menghasilkan analisis yang lebih bermanfaat mengenai peran governace dalam mempengaruhi kinerja prusahaan dail keputusan operasi lainnya, perlu dilakukan pengujian kembali bagaimana mekanisme governace muncul dan bervariasi antar perusahaan

Corporate governance adalah multidimensi, namun beberapa penelitian sebelumnya mengenai corporate governance biasanya berfokus pada variabel criporato governance individu atau membentuk satu metrik corporate governance dengan merijumlahkan variabel individunya, hal ini menjadi tidak tepat untuk mengukur struktur corporate governance perusahaan, dan umumnya menghasilkan kesalahan pengukuran (Larcker, Richardson, dan Tuna, 2007). Padahal beberapa variabel governance individu tersebut cenderung saling terkait, dengan mengabaikan korelasi antar variabel dapat mengakibatkan kesimpulan yarg tidak benar (Agrawal dan Knoeber, 1996).

Penelitian dengan menggunakan agregasi variabel individual governance telah dilakukan oleh Aiyesha Dey (2008), yang membuktikan bahwa keberadaan dan peranan berbagai mekanisme corporate governance pada perusahaan merupakan fungsi dari level konflik keagenan di perusahaan tersebut. Hasil yang sama juga diperoleh oleh penelitian Larcker, Richardson, dan Tuna (2007), serta Rustiarini (2010). Namun berbeda dengan penelitian sebelumnya, penelitian ini mengguji konflik keagenan dengan struktur corporate governance dengan menggunakan indikator yang pernah diteliti dan signifikan berpengaruh di Indonesia. Adanya hasil yang tidak konsisten dari penelitian sebelumnya serta menggunakan agregasi corporate governance dan agregasi konflik keagenan menyebabkan isu ini menjadi topik yang penting untuk diteliti.

\section{KERANGKA TEORITIS DAN \\ PENGEMBANGAN HIPOTESIS}

Teori keagenan menjelaskan tentang pola hubungan perusahaan antara principal dan agen, tujuan utamanya adalah untuk menjelaskan bagaimana pihak-pihak yang melakukan hubungan kontrak dapat mendesain kontrak dengan tujuannya untuk meminimalisir cost sebagai dampak adanya informasi yang tidak simetris. Salah satu cara untuk mengatasi agency conflict adalah dengan monitoring melalui corporate governance. Corporate governance sebagai efektifitas mekanisme yang bertujuan meminimalisasi konflik keagenan dengan penekanan khusus pada mekanisme legal yang mencegah dilakukannya eksplorasi atas pemegang saham minoritas. Mekanisme tersebut meliputi ukuran dewan komisaris, proporsi dewan komisaris independen, kepemilikan manjerial, kepemilikan iıstitusional, komite audit, ukuran komite audit, dan kepemilikan institusional, serta kualitas audit.

Penelitian terdahulu yang dilakukan oleh Hermalin (1988) dan Weisbach (2003) menyatakan bahwa dewan direksi merupakan respon endogen masalah keagenan. Bushman et al. (2004) 
mendokumentasikan bahwa struktur dewan, insentif ekuitas direktur, kompensasi eksekutif, dan konsentrasi kepemilikan bervariasi sesuai sistem akuntans perusalan can kompleksitas organisasi. Klein (2002) mencata bakra independen komite audit meningkat bersama ukuran dewan dan persentase eksternal dewan.

Klapper dan Love (2004) menguji hubungan antara indeks corporate governance credit lyonnais securities asia (CLSA) dan tingkat karakteristik perusahaan pada pasar modal negara berkembang. Studi mereka mencatat bahwa perusahaan dengan pertumbuhan masa laiu yang lebih besar, proporsi aktiva tetap yang lebih rendah, saham yang diperdagangkan di Amerika Serikat, peluang investasi yang semakin baik, konsentrasi kepemilikan yang semakin tinggi, dan kebutuhan yang lebih besar untuk pembiayaan eksternal akan memiliki peringkat governace yang semakin tinggi. Penelitian Zaenal Arifin (2005) yang menguji hubungan antara nilai corporate governance yang diukur dengan index corporate governance dan variabel agensi yang diukur dengan 4 variabel yaitu: dewan komisaris independen, kepemilikan besar, bonding dengan meningkatkan hutang, dan bonding dengan meningkatkan dividen membuktikan bahwa tidak terdapat hubungan yang signifikan antara nilai corporate governance dan variabel agensi. Klein (2002) juga menemukan bahwa komite audit independensi menurun bersama dengan kesempatan tumbuh perusahaan, ketika perusahaan berturut-turut mengalami dua kali atau lebih kerugian dan hadirnya mekanisme pemantauan alternatif. Aiyeshadey (2008) menemukan bahwa perusahaan dengan konflik keagenan yang semakin besar memiliki mekanisme governance yang semakin baik, khususnya yang berkaitan dengan dewan, komite audit dan auditor. Berdasarkan uraian tersebut maka dapat dikembangkan hipotesis sebagai berikut:

$\mathrm{H}$ : Konflik keagenan berhubungan dengan mekanisme corporate governace perusahaan

\section{METODE RISET}

\section{Pemilihan sampel dan pengumpulan data Penelitian}

Populasi penelitian ini adalah seluruh perusahaan manufaktur yang terdaftar di Bursa Efek Indonesia (BEI) selama periode 2002 - 2008. Data yang digunakan dalam penelitian ini adalah data sekunder. Pemilihan sampel dilakukan dengan purposive sampling dengan kriteria yang disajikan pada Tabel 1. Berdasarkan kriteria yang telah ditentukan, maka diperoleh sampel sebanyak 27 perusahaan.

\section{Definisi Operasional Variabel}

2.1. Corporate Governance

a. Komite audit (AC), yang diukur dengan menggunakan variabel dummy, bila perusahaan sampel memiliki komite audit maka dinilai 1 , jika sebaliknya maka dinilai 0 .

b. Ukuran komite audit (ACSIZE), merupakan jumlah anggota komite audit takm seiap perusahaan yang digunakan sangwi dalam penelitian ini.

c. Kualitas Audit (AQ), yang diukur menggunakan variabel dummy, bila perusahaan diandit KAP Big 4 maka dinilai 1, jika sebaiknya maka dinilai 0

d. Kepemilikan Institusional (INSTOWN), yang diukur dengan menggunakan indikator prosentase jumlah saham yang dimiliki institus; dari seluruh modal saham yang beredar.

e. Kepemilikan Manajerial (MGROWN), adalah prosentase jumlah saham yang dimiliki piak manajemen dari seluruh modal zaham perusahaan yang beredar.

f. Ukuran Dewan Komisaris (BOARDSIZE), yang diukur dengan jumlah dewan komisaris suatu perusahaan.

g. Proporsi Dewan Komisaris Independen (BOARDINP), yang diukur dengan menggunakan indikator prosentase anggota dewan komisaris yang berasal dari luar perusahaan dari seluruh ukuran anggota dewan komisaris perusahaan.

\subsection{Konflik Keagenan}

a. Ukuran perusahaan (SIZE), diukur dengan logaritma natural penjualan.

b. GROWTH, menggunakan proksi volatilitas kesempatan tumbuh yang diukur dengan bookto-market ratio

c. RISK OPERATION, yang diukur dengan deviasi standar arus kas operasi dikurangi dengan total aset.

c. Leverage (LEV), diukur dengan rasio hutang jangka panjang terhadap total aktiva (long term debt ratio)

d. Free Cash Flow (FCF), diukur dengan selisih antara laba operasi dikurangi dengan perubahan net asset dari periode sekarang dengan periode tahun sebelumnya.

e. Struktur Kepemilikan (OWNERSHIP), diukur sebagai persentase modal yang dimiliki pemegang saham individu, dihitung sebagai satu dikurangi nilai saham yang dimiliki oleh para eksekutif, direksi, dan investor institusi dibagi dengan total kapitalisasi pasar perusahaan.

\subsection{Teknik Analisa Data}

Analisis data meliputi statistik deskriptif, analisis faktor (Confirmatory Factors Analysis) dan korelasi kanonikal. Analisis faktor digunakan untuk mereduksi empat variabel dependen yaitu kepeinilikan manajerial, kepemilikan institusional, proporsi komisaris independen, dan jumlah anggota komite audit menjadi satu faktor yaitu corporate governance. Analisis ini juga digunakan untuk mereduksi empat variabel independen yaitu 
kepemilikan manajerial, kepemilikan institusional, proporsi komisaris independen, dan jumlah anggota komite audit menjadi satu faktor yaiuu agency. conflict. Confirmatory factors analysis, digunakan untuk mengkonírmasi apakah suatu konstruk yang secara teoritis telah dibentuk dapat dikonfirmasikan dengan data empirisnya (Ghozali, 2006). Korelasi kanonikal digunakan untuk menguji hubungan lebih dari satu variabel independen dan variabel dependen

\section{ANALISIS DATA}

Tabel 1 dan 2 menunjukkan berbagai data deskripsi perusahaan manufaktur yang dijadikan sampel pada penelitian ini. Berdasarkan pada tabel 3, nilai KMO 0,555 dan nilai sig Bartlett's Test of Spericity 0,000 menunjukkan bahwa analisis faktor dapat dilanjutkan. Keenam indikator hasil ekstrasi menjadi dua faktor, faktor 1 mampu menjelaskan $27,64 \%$ variasi sedangkan faktor 2 mampu menjelaskan sebesar $53,31 \%$ variasi, sehingga kedua faktor secara keseluruhan mampu menjelaskan 80,95\% variasi. Berdasarkan hasil rotated component matrix, yang mengelompokkan faktor 1 meliputi ukuran perusahaan, pertumbuhan, dan free cash flow semuanya dengan loading faktor diatas 0,50 . Sedangkan faktor 2 meliputi Leverage, risiko operasi, dan struktur kepemilikan.

Berdasarkan tabel 4, nilai $K M O 0,481$ dan nilai sig Bartlett's Test of Spericity 0,000 menunjukkan bahwa analisis faktor tidak dapat dilanjutkan sehingga harus menghilangkan satu variabel dengan nilai korelasi terkecil, yaitu kepemilikan manajerial. Hasil pengujian berikutnya nilai KMO 0,547 dan nilai sig Bartlett's Test of Spericity 0,000 menunjukkan bahwa anaiisis faktor dapat dilanjutkan. Keenam hasil ekstrasi menjadi dua faktor, faktor 1 mampu menjelaskan 34,59\% variasi sedangkan faktor 2 mampu menjelaskan $59,23 \%$ variasi, sehingga kedua faktor secara keseluruhan mampu menjelaskan $93,82 \%$ variasi.

Berdasarkan hasil rotated component matrix, yang mengelompokkan faktor 1 meliputi komite audit dan jumlah komite audit yang mempunya loading faktor 0,96 dan 0,95 . Sedangkan faktor 2 meliputi kepemilikan institusi, ukuran dewan komisaris dan kualitas audit. Satu variabel yang tidak bisa masuk faktor 1 dan 2, yaitu ukuran dewan komisaris independen.

Berdasarkan analisis, kelima fungsi kanonikal terlihat pada Root No dengan angka korelasi fungsi 10,86 , fungsi kedua 0,66 . fungsi ketiga 0,25 , fungsi keempat 0,15 dan fungsi kelima 0,09. Untuk korelasi kanonikal pertama, covariate variabel kanonikal mampu menjelaskan $73,96 \%$ $\left(0,86^{*} 0,86\right)$, sehingga ini lebih peniing dari fungsi lainnya. Dilihat dari kolom signifikan yang menguji fungsi kanonikal, fungsi 1 sigifikan pada 0,000 juga dengan fungsi 2 . Sedangkan fungsi fungsi 3,4 , dan
5 mempunyai signifikan $0.106,0.405$ dan 0.439 , berarti fungsi 3, 4 dan 5 tidak bisa dianalisis lebih lanjut secara individual.

Dengan menggunakan empat prosedur car: Pillais, Hotellings, Wilks, dan Roys, semuanya signifikan karena $<0,05$. Dengan demikian jika digabung secara bersama-sama, kanonikal fungsi 1 dan kanonikal fungsi 2 dapat diproses lebih lanjut. Hasil pengujian individu dan bersama (kolektif) terdapat perbedaan korelasi kanonik yaitu terlihai pada tabel 4.14, dengan angka korelasi kanonik fungsi $1=0,86$, dan korelasi kanonikal fungsi $2=$ 0,664 . Oleh karena fungsi 1 memiliki angka korelasi kanonikal yang tinggi dan signifikan baik secara individu maupun kolektif, maka analisis selanjutnya hanya menitik beratkan pada fungsi 1 .

Berikutnya adalah pengujian kanonikal Weights dan kanonikal Loadings dengan dependent kanonikal variate (INSTOWN, BOARDSIZE, AC, ACSIZE, $\mathrm{AQ}$ ) dan independent kanonikal variate (SIZE, GROWTH, LEV, FCF, OPERATION RISK, dan OWNERSHIP). Pengukuran dengan Kanonikal Weights menunjukkan satu angka korelasi yang tinggi yaitu 0,995 kepemilikan institusional. Sedangkan untuk variabel independen angka korelasi tinggi $-0,988$ struktur kepemilikan. Pada pengukuran Kanonikal Loading menunjukkan angka tinggi kepemilikan institusional 0,959 . Sedangkan variabel independen stuktur kepemilikan $-0,976$. Berdasarkan hasil perhitungan diatas, maka diperoleh hasil sebagai berikut:

a. Variabel dependen dan variabel independen memiliki hubungan yang signifikan. Dengan perkataan lain terdapat hubungan antara kepemilikan institusional, ukuran dewan komisaris, komite audit, jumlah komite audit, dan kualitas audit terhadap ukuran perusahaan, pertumbuhan, risiko perusahaan, leverage dan free cash flow perusahaan jika dilakukan pengujian secara kelompok.

b. Dari lima Pada pengukuran dengan independen, ada satu pada pengukuran dengan yang memiliki hubungan yang yang sangat tinggi namun negatif yaitu struktur kepemilikan (OWNERSHIP) dengan kepemilikan institusional (INSTOWN). Dengan demikian dapat diartikan perusahaan yang mempunyai struktur kepemilikannya rendah memiliki kepemilikan institusional yang tinggi. Perusahaan yang memiliki mekanisme corporate governance yang tinggi mempunyai konflik keagenan yang rendah.

\section{PEMBAHASAN DAN KESIMPULAN}

Konflik keagenan berkorelasi terhadap struktur corporate governance. Beberapa hal kemungkinan yang dapat menyebabkan konflik keagenan berhubungan dengan corporate governance yaitu: (1) manajemen perusahaan akan 
mendapat manfaat jangka panjang dari penerapan corporate governance, (2) keberadaan dewan komisaris dan komite audit dalam perusahaan dapat memantau perusahaan dalam melaksanakan corporate governance, (3) peningkatan kepemilikan saham oleh manajemen dan investor institusi menyebabkan tekanan kepada perusahaan untuk menerapkan corporate governance pun semakin besar. Hal ini konsisten dengan penelitian Aiyeshadey (2008) yang menemukan bukti bahwa konflik keagenan berhubungan positif dengan struktur governance. Konflik keagenan dan mekanisme governace saling melengkapi, semakin tinggi konflik agensi akan menghasilkan struktur governace yang semakin kuat. Secara khusus hasil penelitian ini membuktikan adanya hubungan negatif antara struktur kepemilikan dan kepemilikan institusional. Perusahaan dengan kepemilikan institusional yang tinggi memiliki struktur kepemilikan yang rendah. Hal ini diartikan bahwa semakin tinggi perusahaan melakukan corporate governance semakin rendah konflik keagenannya.

Perbedaan penerapan corporate governance di negara yang maju dengan sedang berkembang menjadi alasan bahwa di Indonesia corporate governance belum disadari sepenuhnya oleh perusahaan - perusahaạn. Moh'd et al. dalam Pratana dan Mas'ud. (2003) menyatakan bahwa investor institusional merupakan pihak yang dapat memonitor agen dengan kepemilikannya yang besar, sehingga motivasi manajer untuk mengatur laba menjadi berkurang dan menyebabkan konflik keagenan yang terjadi semakin rendah.

Berdasarkan hasil analisis dan pengujian data dapat disimpulkan bahwa variabel konflik keagenan berhubungan dengan corporate governance jika dilakukan pengujian secara berkelompok, sedangkan secara individual yang memiliki hubungan erat adalah struktur kepemilikar dan kepemilikan institusional.

\section{DAFTAR PUSTAKA}

Agrawal, A., and C. Knoeber. 2006. Firm Performance and Mechanisms to Control Agency Problerns Between Managers and Shareholders. Journal of Financial and Quantitative Analysis 3: 377-97.

Arifin, Zaenal. 2005. Hubungan antara Corparete Governance dan Variabel Pengurang Masalah Agensi. Jurnal Siasat Bisnis, 10 Vol. 1, Juni.

Bushman, R.; Q. Chen; E. Engel; And A. Smith. 2004. Financial Accounting Information,
Organizational Complexity and Corporate Governance Systems. Journal of Accounting \& Economics 37: $167-$ 201.

Dey, Aiyesha. 2008. Corporate Governance and Agency Conflicts. Journal of Accounting Research, Vol. 46 No. 5 Decenber.

Ghozali, Imam. 2006. Aplikasi analisis Multivariate dengan Program SPSS. Edisi IV Cetakan keempat, Badan Penerbit Universitas Diponegoro, Semarang.

Ghozali, Imam. 2009. Analisis Multivariate Lanjutan dengan Program SPSS. Badan Penerbit Universitas Diponegoro, Semarang.

Hermalin, B., And M. Weisbach. 2003. Boards of Directors as an Endogenously Determined Institution: A Survey of the Economic Literature. Economic Policy Review 9: 7-26.

Jensen, Michael C. dan W.H. Meckling. 1976. Theory of The Firm: Managerial Behavior, Agency Cost and Ownership Structure. Journal of Financial Economics 3. hal. 305-360.

Klapper, L., And I. Love: 2004. Corporate Governance, Investor Protection, and Performance in Emerging Markets. Journal of Corporate Finance 10: 70328.

Klein. 2002. Audit Committee, Board Of Director Characteristics and Earnings Management. Journal of Accounting and Economics, Vol.33. No.3. August, hal.375-400.

Larker, D.; S. Richardson; and I. Tuna. 2007. Corporate Governance, Accounting Outcomes and Organizational Performance. The Accounting Review 82.

Midiastuty, Pratana Puspa dan Mas'ud. 2003. Analisis Hubungan Mekanisme Corporate Governance dan Indikasi Manajemen Laba. Simposium Nasional Akuntansi VI. IAI-Kompak.

Rustiarini, Ni Wayan. 2010. Pengaruh Corporate Governance pada Hubungan Corporate Social Responsibility dan Nilai Perusahaan. Simposium Nasioal Akuntansi XIII, IAI-Kompak. 